\title{
Widening Participation Praxis and Library Leadership
}

\begin{abstract}
This chapter theorizes academic libraries and library workers ${ }^{1}$ as partners in social justice work in higher education, linking the core concerns of critical librarianship (or Critlib) to library leadership practices that can enable and facilitate widening participation as a political project. Widening participation, as a policy imperative and higher education practice, attempts to improve access to higher education among under-represented groups. However, rooted in the logic of marketized, neoliberal higher education, liberal approaches to widening participation are instrumentalist and contribute to a cultural discourse which reproduces inequity and unequal educational outcomes.
\end{abstract}

Drawing on Nancy Fraser's model of social justice and critical sociology of education, particularly the work of Penny Jane Burke and Diane Reay, this chapter develops a critical theory of library leadership which radically reframes widening participation practice as a project of recognition and inclusion. In connecting the rich scholarship of Critlib movement, particularly critical information literacy and library pedagogies, to shared commitments to social justice between library and other education workers, this chapter deepens our theoretical understanding of libraries' contributions to widening participation.

Keywords: Widening participation; critical librarianship; critical information literacy; critical pedagogy; higher education; reflective practice; social justice

Publication: This author accepted manuscript is deposited under a Creative Commons Attribution Non-commercial 4.0 International (CC BY-NC) licence. This means that anyone may distribute,

\footnotetext{
${ }^{1}$ Throughout this chapter, following Barron and Preater (2018 p.88) library worker is used as an inclusive term covering anyone whose roles include library and information work, regardless of job title, qualification or credentials.
} 
adapt, and build upon the work for non-commercial purposes, subject to full attribution. If you wish to use this manuscript for commercial purposes, please contact permissions@emerald.com.

Published as: Preater, A. (2020), "Widening participation praxis and library leadership", Hines, S.S. and Ketchum, D.H. (Eds.) Critical librarianship (Advances in library administration and organization, Vol. 41), Emerald Publishing Limited, pp. 21-40. https://doi.org/10.1108/S0732$\underline{067120200000041003}$

\section{Introduction and Autobiography of the Question}

Widening access and participation (WP) refers to policy efforts to both increase access to higher education generally, and specifically to improve access and outcomes for groups that have been excluded from and marginalized within higher education. This chapter will develop a critical theory and practice which connects library leadership with WP practice, informed by the practice and scholarship of critical librarianship, "a movement of library workers dedicated to bringing social justice principles into our work in libraries" (Critlib, n.d.). This follows Schroeder \& Hollister's (2014 p.94) definition of critical practice as, "the application of a critical theory to one's professional life or [...] societal environment." This connects to Freire's concept of praxis meaning, "reflection and action directed at the structures to be transformed," (1996 p.107, emphasis in original) which is at the heart of Freire's project of education as a means of informing critical, transformative interventions in the world. This critical practice is positioned as one in which academic library leadership aligns with WP as a practice of social justice, ultimately rooted in a critical theory imperative for liberation based on individual freedom; summarized in Horkheimer's "demand that we construct a better social totality" (2012, p.139).

In approaching this idea, Miller's concept of the autobiography of the question (1995) is employed, which diverts from impersonal academic style and works to historicize the question addressed. WP is a field of academic research and scholarship as well as an educational professional practice, and the work of critical theorists of education provide the analytical and theoretical frames 
for this chapter. Formative work in this area includes Crozier \& Reay's (2011) analysis of workingclass students "learning how to learn in higher education," which employs Bourdieu's concepts of cultural and social capital (1986), Stevenson \& Clegg's understanding of the importance of learners' reflexivity toward their future orientation (2013), Skegg's sociological analysis of respectability as a class signifier (1997), Reay’s (2001) work that surfaces subjective feelings of pretension and impostorship in working-class experiences of education.

An academic from a working-class background, Reay (2018, p.1) discusses her "shock of recognition" and developing understanding on reading Jackson \& Marsden's Education and the Working Class (1966). The author's own shock of recognition was in experiencing Burke \& Crozier's (2014) Foucauldian analysis of power in education in a traditional academic conference paper presentation. Burke \& Crozier describe institutionalized processes of exclusion based upon on what is recognized and culturally valued within the academy - that is by middle-class students and faculty—and how difference is used to mark students out and misrecognize them based on status inequality (Fraser, 2003). This resonated strongly with the author's own experience of education at a selecting institution at which,

"Students from working-class backgrounds have to struggle to assert their authenticity and their right to be at university at all, and they often struggle with their own perceptions of learner identity" (Burke and Crozier, 2014).

In theorizing experience of higher education, the chapter refers to the WP student as a shorthand descriptor, acknowledging this term used as a grouping masks wide diversity of identities and experiences, as well as the WP subject. In the latter term, Foucault's (1982) dual meaning of the term subject is employed to refer to both the objectivizing of the subject by processes which Foucault names "dividing practices," and also the processes by which people recognize themselves as such, in Foucault's terms, "the way a human being turns [themselves] into a subject" (p.778). 


\section{Widening Participation and Access in England}

In England, in common with many minority-world countries ${ }^{2}$, WP has been developed as a strategic concern of government and funder policy following the mid-20th century expansion, massification, and democratization of higher education. WP, as a concern of political economy within an increasingly knowledge-based economy, was intensified following the New Labour government's 2001 manifesto aim of 50\% participation of "young people before they are 30" in higher education by 2010 (Labour Party, 2001 p.20). WP practices are now a key component of institutional and policy discourses of equity and equal opportunity, and in England the higher education regulator the Office for Students (OfS) is increasingly linking access and participation outcomes to funding (OfS, 2018a).

There is a tension central to WP in higher education between access and participation as a practice of equity linked with social justice, and a more instrumental human capital (Becker, 1993) view of WP as a necessary step in developing the workforce prepared for current and future employment within a knowledge-based economy. The latter has been the framing employed by successive UK governments. Hinton-Smith (2012) characterizes this binary as, "[t]he gap between ideological social equity rhetoric and the reality of limits to both HE participation and graduate employment opportunities causes inevitable stress as individuals feel frustrated in finding their attempts to realize their potential $[\ldots]$ thwarted" (p.9). One illustration of the success of neoliberalism as an ideological project is how inequalities and circumscription of opportunities are presented here as "reality."

In the United Kingdom, debate about equity and WP has tended to focus on access to undergraduate degree courses by those from disadvantaged backgrounds who are otherwise academically capable. This draws on the mainstream discourse of meritocracy, a liberal ideal that

\footnotetext{
${ }^{2}$ As in Barron \& Preater (2018 p.89) this chapter follows Alam's (2008) coinage "majority world" rather than for example, the Third World or developing countries, and its inverse minority world rather for example, the First World or developed countries.
} 
fair access for individuals should be enabled as a moral imperative to "ensure that all those who have the ability, aptitude and potential to benefit from a university education have a fair chance to do so" (Millburn, 2013). However, a metric-driven view of under-representation presents a more complex picture, with the higher education regulator in England defining "under-represented groups" as:

- Students from areas of low higher education participation, low household income and/or low socio-economic status

- Students of particular ethnicities

- Mature students

- Disabled students

- Care leavers

(OfS, 2018b p.8-9).

Although socio-economic status is listed, the official UK socio-economic classification was discontinued from the official higher education statistics in 2017 (HESA, n.d.) which means other indicators tend to be employed as proxies for social class. The regulator also considers the following groups under-represented based on specific evidence of barriers to equal opportunity:

- Carers

- People estranged from their families

- People from Gypsy, Roma and Traveller communities

- Refugees

- People with specific learning difficulties and mental health problems

- Children of military families

(OfS, 2018b p.9).

Under-representation based on participation is by definition a relative term, and it can be seen from these lists that under-representation itself does not always map neatly to the common 
understanding of a disadvantaged group within Critlib movement or the wider public imagination. It excludes for example first-generation students as a group, and does not explicitly address intersectionality, meaning how forms of social stratification or oppression are interwoven, a theory developed by Black feminist scholars (Crenshaw, 1989). However, the regulator has shown regard to intersectionality elsewhere, including during consultation with the higher education sector (OfS, 2018c). These identities, and broader groupings such as "WP students," "non-traditional students," or "groups historically excluded from higher education" remain problematic as they are constructed by and within the power relationships of higher education policy. This approach masks complexity within groups and identities, can be read as implying homogeneity where diversity exists, and can create division and exclusion because, as Hall (1996) argues, identities "emerge within the play of specific modalities of power, and thus are more the product of the marking of difference and exclusion" (p.4).

As well as access, the regulator is also concerned that universities reduce and eliminate gaps between under-represented groups and other groups in terms of attainment and progression from higher education into employment, including an explicitly neoliberal linkage between success in higher education and "successful and rewarding careers" (OfS, 2018a p.12). This attention to attainment and progression, and its metricization, is significant for libraries as these are sites of students' shaping and developing their identities as independent learners, particularly in the development of reading and writing as academic literacy practices which are heavily implicated in assessment.

The evidence of the effectiveness of policy is that WP has not been taken up in an equal or balanced way across English higher education, and it is less-selective or recruiting universities that have done most work in WP. For example, in 2016-17, the selecting University of Durham recruited 170 students (5.2\%) from neighborhoods with low participation to higher education, whereas the similar size recruiting Teesside University recruited 635 (30.5\%) students from low participation neighborhoods (HESA, 2018). Differences in recruitment of students from BAME (Black, Asian 
and minority ethnic) ${ }^{3}$ backgrounds between selecting and recruiting universities can be startling. For example, in 2016-17, the number of Black students at a single recruiting university, London South Bank, was 4,205 of a total 16,190 UK-domiciled students. This is just less than the number of Black students at all five of the selecting London Russell Group universities combined, at 4,395 of 68,120 UK-domiciled students (HESA, 2018). This lack of diversity at selecting universities is critiqued by Bhopal both in terms of inequality in admissions processes, and in how this creates and sustains spaces that are supportive of white middle-class identities and practices, with universities "measur[ing] a particular type of success that is possessed by those from white middle-class backgrounds" (2018 p.92-93).

The author categorizes universities as selecting compared with recruiting both as an accurate descriptor and a refusal of the classism implicit in terms such as elite or prestigious. However, these descriptors deserve unpacking to understand stratification of English higher education in the neoliberal context. What marks universities as elite is based partly on students' entry requirements making them often highly selective, but institutions are also differentiated and stratified according to other markers of reputation. These include the intensivity and reputation of their research activity and quality, their assets and income, and their longevity as institutions; but also, more implicit or unspoken markers of who the institution is for-of who is welcomed and will find a place of belonging there. Brown (2018) argues this type of stratification is grounded in the pressures created by the marketization of higher education, which since the 1980s has under neoliberalism created a winner-takes-all market. This competitive market has not led to a range of new, creative possibilities for higher education provision as might be expected theoretically, but a tendency for selecting universities to create a similar undergraduate offer focused on traditional campus-based educational experiences, which has resulted in additional stratification and social distance between different universities. The net result is one which has had negative effects on diversity and equity

\footnotetext{
${ }^{3}$ The term 'BAME' is widely used in UK higher education policy, and is used as a descriptor with acknowledgement that it is a limited and problematic term (Equality Challenge Unit, 2019) which can ignore difference within as well as between communities.
} 
(Brown \& Carasso, 2013 pp.123-143), such that within contemporary higher education we see how "class inequalities in higher education have shifted from being primarily about exclusion from the class system to being about exclusion within it" (Reay, 2018 p.118). Given the espoused values of universities toward equity and the good intentions of practitioners, it is a deep irony of instrumentalist, metricized WP that "resources specifically intended to create greater equity become complicit in the reproduction of social, cultural and symbolic inequalities" (Burke \& Lumb, 2018 p.18).

\section{Academic Libraries as Contributors to WP}

It is uncontested that academic libraries contribute to universities' WP activities, especially in collaboration with the outreach teams or departments where ownership of this work usually rests. Typical activities include events that raise awareness of library materials as sources to off-campus community groups, for example programs and visits designed to familiarize school and further education students with academic library environments (Anderson \& Bull 2014), and information resources and study skills support for students' self-directed project work (Cripps, Anderson, Strauss \& Wheeler, 2018; Ackerley \& Wilson, 2012). Library outreach activities, in common with the strategic aims of wider university outreach, also play a role in marketing and student recruitment with activities designed to engage those outside the university campus community to "advance awareness, positive perceptions, and use of library services, spaces, collections, and issues" (Diaz, 2019).

Rickard (2016) terms activity other than genuine community engagement "in-reach" rather than outreach, as such activity is really designed to "promote awareness of the library among those who, although eligible, remain non-users" (p.15). Positively, Lebeau \& Bennion (2014) identify these outward-facing activities as part of a recent strategic moves by universities to demonstrate engagement locally and regionally, arguing this is one way "universities can contribute to social justice and community inclusiveness," beyond accredited courses. Rickard's (2016) insight from her 
review of the literature is that WP activities and outreach typically address awareness-raising among non-users. Librarianship's professional body of knowledge shows relatively little contribution to WP as a political project of social justice and social mobility, which the author argues is rooted in library workers' acceptance of middle-class dispositions and subjectivities within higher education. Hegemonic, instrumentalist WP approaches see libraries as a site of instruction, academic skills training, and a store of cultural capital in the form of information resources. As such libraries' WP activities are framed in an instrumental way rather than with understanding of the potential of libraries as a discursive space which can nurture students' academic identities and sense of belonging within the university as a community of learners.

\section{Academic Libraries as Spaces of Marginalization and Exclusion}

A central argument of this chapter is that academic library workers and our institutions develop and reproduce cultural misrecognitions of WP subjects. Misrecognition, theorized by Bourdieu (1993 p.81) is a social practice in which the underlying generative structures within a particular field are not consciously acknowledged in terms of the social stratification or differentiation they reproduce. Here, field refers to one of the core concepts of Bourdieu's sociology (1993 pp.29-73), which describes how social formations are structured and arranged hierarchically. A field may be defined as, "a structured space with its own laws of functioning and its own relations of force independent of those of politics and the economy" (Bourdieu, 1993 p.6). For instance, academic librarianship or WP practice may be thought of as fields.

Relating misrecognition to power and Bourdieu's concepts of field and forms of capital, Webb et al. (2017 p.9) argue this occurs within higher education, "when power relationships based on who has access to different economic capital within fields morph into symbolic capital to legitimize a hierarchy of different worth." The term misrecognition is also used in an overlapping but distinct sense by Fraser to describe a form of inequality in status, based on how institutions acknowledge and stratify different forms of cultural value. This sense is integrated within Fraser's (2003) status 
model of recognition and theory of justice (2007). In this later, more developed model Fraser describes injustice working in three areas or dimensions:

- An economic dimension, reflecting maldistribution of resources

- A cultural dimension, reflecting misrecognition based on cultural value

- A political dimension, reflecting misrepresentation based on political exclusion

In both senses described by Bourdieu and Fraser, those with power-ultimately rooted in access to economic capital — are able to construct and develop hierarchical systems which sustain their positions of privilege, and are better positioned to determine those capitals which become viewed as most valuable within a particular field. For the author, the bases of these acts of misrecognition are thoroughgoing and embedded within everyday practice in the field of academic librarianship, such that they represent a taken-for-granted set of common-sense assumptions, or in the sense meant by Gramsci (1971 pp.5-23) a position of cultural hegemony. These include:

- The long-standing pursuit of non-neutrality and objectivity to develop library and information science as a "neutral social science," building upon the ideals of classical liberalism (Dick, 1995).

- The snug fit of the constructed culture of middle-class whiteness of librarianship (Galvan, 2015 ) to the subject positions of middle-class white experience of higher education which mark out the "good student" (Grant, 1997).

- Policies and other formal expectations based around an imagined model student who is independent, well-behaved and studious, in keeping with the "socially dominant discourses of academic life" (Read, Archer, \& Leathwood 2003).

- In our collection management and development, our privileging of limited forms and knowledge and ways of knowing which are rooted in the "Eurocentric masculinist knowledge-validation process" of our academic communities and which shape our 
assumptions (Collins, 1989); and our attendant lack of support for BAME academic and student leadership in challenging whiteness in the curriculum (Hussain, 2015).

- The embedding of algorithmic bias within library search and discovery systems (Riedsma, 2019), alongside existing ideological bias in our classification schemes (Drabinski, 2013).

- Anti-theoretical approaches to our intellectual work which in emphasizing practicality prevents the development of spaces for critique and critical discourse, in turn naturalizing existing power structures and "reproduc[ing] conditions through which whiteness sustains its dominative power" (Hudson, 2017).

- Our broadly uncritical acceptance of deficit models which conceptualize WP students and their communities as lacking or deficient in terms of their knowledge and experience. Deficit models are employed both to explain differences in educational outcomes (Terrile, 2019) and to justify additional—separate — support to overcome perceived weaknesses (Gorard et al., 2006 pp.119-120).

An example of the sense of marginalization and feelings of being an outsider to higher education practices by Aisha, a WP student, is relayed by Burke (2012) in the student's reflective journal entry,

"I thought I'd update you on my trip to the library. As I arrived I was determined to get help so I approached one of the staff at the library counter and explained that I was new and that I had some problem using the library at home. With a big smile the lady directed me to one of the computer desk and asked to follow the instructions. She added that it was straightforward and usually students find it very easy to use and she pointed to some leaflets which were self explanatory (according to her). At that point I felt too shy to express my despair to have more support. So I used the computer, obviously got confused and ended up annoying the student next to me who was more helpful. I am probably 'thick' and computing is definitely not my strength" (p.94). 
This account is quoted at length both because its everyday nature will be recognizable to many library workers, and because the library reported in this way as a site of exclusion is rare within the literature. Burke's point about this crystallized moment in one student's experience is that Aisha has internalized and reproduced a deficit model of WP within herself. In the final sentence we see, in Foucault's (1982) sense, the way process and structure shapes the student's own subjectivity which contrasts with the presentation of welcome and apparent helpfulness of the library worker. Such everyday experiences shape students' expectations of library spaces and services, and constitute generative moments of what Foucault (1995) characterized as "micro-power."

For library leaders there is potential for practical action beyond liberal positions of neutrality or welcoming, which connect to the experience of WP students and recognize the ways in which students' choices and engagement are often circumscribed by competing demands and pressures. Burke, Bennett, Bunn, Stevenson, \& Clegg (2017 p.43) discuss the impact of these demands on students' educational experiences, exploring how these pressures "[make] students more prone to instrumentalising their approach to study, which can limit their pedagogical capacity and engagement with deeper/conceptual understandings related to their degree program."

Thompson (2018) argues that libraries can be spaces of community or "non-judgmental spaces," as unlike lecture theaters, tutorial or seminar classrooms we sit outside the culture of assessment of higher education. The potential of these non-judgmental spaces is as a site for developing what Burke (2012 p.187) terms “safe learning spaces.” Within such spaces, Burke argues, students "have access to, and work through, unfamiliar ideas without the fear of making 'mistakes."' The library conceptualized as a safe learning space is one which is simultaneously challenging and enabling to students' learning, and supports library workers' ability to recognize the forms of knowledge which WP students bring to their experience of education; however, within dominant discourses of higher education pedagogy, this is one we need actively to shape and construct.

Because these positions are counter-hegemonic, they carry a risk of "othering" or marginalization to those enacting them, but as with any counter-hegemonic position, there is a 
lower degree of risk to those with more privileged identities. This approach requires support from leaders with positional power_ from the top — as well as a transforming approach to leadership (Burns, 1978), which raises the ethical aspirations of leaders and followers at all levels within our libraries. Additionally, though, Burke \& Jackson (2007) argue from a feminist poststructuralist perspective that institutions do not simply reproduce dominant ideological positions, rather they are "also sites of struggle and instances where subversions and small changes might take place" (p.222). In this way, we can connect a non-judgmental stance to opportunities for "subversions and small changes" afforded within the everyday interactions between students and library workers, which support political acts of recognition within libraries as a social context.

\section{Critlib Leadership that Contributes to Socially-just WP}

In practice, the discursive power of neoliberalism in its expression as marketized higher education (Brown \& Carasso, 2013) has created a highly resilient status quo position resistant to practices of social justice. The logic of our status quo is the logic of markets and competition, which informs policy-making, governance, strategy and regulation, and has infused our everyday practice of education work. Within academic libraries, this logic has developed within our work a liberal approach in which social justice is reduced to box-ticking and diversity initiatives (Hathcock, 2015) which leave the structural system of oppression, which hooks (1984) names as white supremacist capitalist patriarchy, unproblematized and undisturbed.

There is potential and opportunity for library leaders at all levels to approach these issues differently, by reframing and reconceptualizing how we approach our work within WP. Drawing on Fraser's (2003) theory of social justice, Burke (2012 p.177-188) argues for conceptualizing WP differently, by focusing leaders' WP practice toward social justice concerns; by developing participatory pedagogies with a base within critical and feminist pedagogies; and by paying critical attention to dual perspectives of cultural misrecognition and economic maldistribution affecting WP 
students. It is this multifaceted reconceptualization of WP this chapter will focus on below on as an area for library leadership to develop a new praxis of WP.

As a teacher, Burke centers the importance of pedagogy as "a central area of lived, relational and embodied practice in higher education" (2012, p.183). In a body of work from 2002 onward, Burke critiques WP practice, advocating for a reframing of WP and developing new, collaborative pedagogies. Citing Freire (1994; 1996) as a key influence, Burke (2012) adds critique and insights of poststructuralist feminist pedagogy to develop a "participatory pedagogy" which is "concerned not only with explicit practices of teaching and learning but also with the construction of knowledge, competing epistemological perspectives and the ways that learning and meaning might be assessed to support pedagogical and meaning-making processes." It is this deeper question of meaning-making which Burke and Crozier (2013 p.13-14) articulate, informed by Freire's method, in asking how teachers can facilitate meaning-making as a dialogic process with their students.

A key overlap and alignment between Critlib movement and critical sociology of education lies in critical and feminist pedagogies, and presents both a clear inroad in practice and a developed theoretical foundation. Burke's participatory pedagogy builds upon critical pedagogy, which is a central concern for Critlib movement via discourses and practice of critical information literacy and feminist library pedagogy. If critical pedagogy is "what emerges when critical theory encounters education," (Kincheloe \& Steinberg, 1997 p.24) critical information literacy may be thought of as the encounter between critical pedagogy and library information literacy practice. In Elmborg's (2006) definition, critical information literacy "involves developing a critical consciousness about information, learning to ask questions about the library's (and the academy's) role in structuring and presenting a single, knowable reality." Here there is a clear connection to Freirean critical pedagogy, with "critical consciousness" Freire's term referring to the ability to "intervene in reality in order to change it," (2005 p.5) illuminated by a critical awareness of the political and societal contradictions around us. Freire, as a theorist, has been central to Critlib movement, with Beatty (2015) noting the importance of his Pedagogy of the Oppressed (1996) on critical librarianship 
based on a consensus interpretation from our literature that posits a dialogic and reflective "problem-posing education" as a replacement for the dominant "banking model" of education. Critical information literacy is overtly political, as in Kapitzke's (2003 p.9) definition framed in terms of political economy and ideology, in which a critical information literacy is one which would "analyze the social and political ideologies embedded within the economies of ideas and information."

Critical information literacy is a well-developed area of library and information scholarship with an extensive practical and theoretical literature dating to the early 2000s (reviewed by Tewell, 2015). In practice, critical information literacy and pedagogies are by no means dominant as a frame or method, but have become influential within the literature including practitioner-focused handbooks (McElroy \& Pagowsky, 2016a; 2016b), collections integrating theory and practice (Drabinski, Kumbier, \& Accardi, 2010), and feminist library pedagogy (Accardi, 2013). This provides a footing from which leaders can make progress based on library workers' existing awareness of critical information literacy, an element of what Hudson (2016) describes as "a recent qualified embrace of critical theory" within librarianship. One quantitative example of this is an analysis by Hollister, Brower, \& Schroeder (2017) who note that critical information literacy had been the dominant theoretical frame in the journal Communications in Information Literacy over the journal's lifetime. In response to this Bernardo (albbernardo 2017a; 2017b) characterizes critical librarianship as a perspective which is moving from the margins to center, having accrued cultural capital through librarianship's academic discourse, "Critlib is $[\ldots]$ an outsider perspective that's become the mainstream of high-level professional discourse. And one to which you must subscribe if you want to be taken seriously, or part of the in-crowd." As such, critical information literacy and pedagogies represent a logical area for library leaders to focus attention in supporting by developing its use as an element of a participatory pedagogy, including in connection to opportunities afforded within our institutions' departments supporting academic continuing professional development. 


\section{Cultural Recognition and Misrecognition}

The positions and subjectivities WP students experience and inhabit are not fixed or essential categories; as Skeggs (1997 p.94) argues, "Identities are continually in the process of being re-produced as responses to social positions, through access to representational systems and in the conversion of forms of capital." It is within library workers' capabilities to alter these social positions based on changing our interactions with students, reworking the educational experiences we provide, and centrally reframing the ways we recognize the social and cultural capitals of WP students and their communities. In this way we can illuminate and then problematize the unspoken assumptions that ascribe WP students essential and pathologizing characteristics based on identity, bringing into the open those hidden "systems of inscription and classification (which work in the interests of the powerful)" (Skeggs, 2003 p.4).

Skeggs (1997, p.12), in her ethnographic study of class and gender, argued restrictions on access to knowledge and capitals are key to subject formation as, "Economic positions, institutional position, subject positions and discursive positions are not all equally accessible," and also are deeply entwined with prior social and familial experiences. Central to the work of academic libraries is intentional selection of and providing access to "large reserves of cultural capital" (Goulding, 2008 p.236) in the form of information resources, independent use of which is one way learners develop embodied cultural capital (Bourdieu, 1986). In this way, libraries and library workers act as a "legitimizing agent for cultural artefacts $[\ldots]$ which gives the impression of acceptability of the materials provided" (Hussey, 2010 p.49). However, these expectations of independent study and engagement with library resources speak to assumptions in our practice about how students "develop strategies to build self-confidence and self-reliance, thus becoming the kind of student $[\ldots]$ recognized as 'independent' and 'resilient"' (Burke, Bennett, Burgess, Gray \& Southgate, 2016 p.43). A key step for library leadership is to understand how liberal positions of welcome or inclusion depend upon students' subjectivities molding to these dominant discourses of education - meaning it is those with particular characteristics who are most easily welcomed and 
will feel most included. It is this sense of mismatch between WP subjectivities and higher education's valorization of middle-class social and cultural capitals which Reay, Crozier \& Clayton (2013) associate with a sense of discomfort, impostorship, and of "“fitting in' or 'standing out"” that working-class students experience within the "starkly unfamiliar field" (p.120) of a new educational setting.

Recognizing and rethinking our work in access and legitimation of cultural capitals implies reconceptualizing how we think about knowledge creation and validation within academic communities, as well as attention to practice within academic libraries. Our dominant conceptualizing of knowledge sits within a marketized consumerist framework, which views knowledge as "an instrumental set of notions external to the subject rather than a transformation of the self' (Mavelli, 2014). An alternative framing for library workers is to focus on the strengths in the forms of capital that WP students bring to higher education settings and in this regard; Yosso's concept of community cultural wealth, developed from a critical race theory critique of Bourdieu's social and cultural capital is instructive. Yosso (2005 pp.77-81) identifies six forms of capital which center the epistemological frames of communities of color, these are:

- Aspirational capital, the ability to maintain hope in the face of adversity and barriers.

- Linguistic capital, the skills and social experience gained from multilingual experience.

- Familial capital, the ways of knowing developed from experience of kinship ties within extended family settings.

- Social capital, supportive networks of people and community resources.

- Navigational capital, the competencies and cultural strategies needed to maneuver within social institutions.

- Resistant capital, knowledge developed from experience of resistance to and challenging of inequality. 
Based on Yosso's work, Stevenson (2019 p.43-44) developed for the English higher education setting a set of critical questions to reflect on our interactions with students, to shed light on the deficit models we hold as education workers. In working actively to recognize the cultural wealth held by marginalized learners and communities, library workers can begin to destabilize those cultural misrecognitions which are rooted in the white, middle-class cultural capitals valued within and reified by higher education. Library leaders may of course personally reject individualized notions of deficit and the institutional classifications that underpin them, but in practice a more powerful strategic move is to normalize using the types of critically-reflective questions that recognize the right of WP students to define and conceptualize their own knowledge and knowledge production.

For example, in considering library workers' conversations with faculty about authorship and the dominance of white, western perspectives within in the curriculum we may draw on Stevenson's (2019 pp.43-44) questions to ask for example, “Are our curricular practices dominated by Eurocentric voices?" "Do we draw on 'non-western' and non-white forms of knowledge in our teaching?" and "To what extent does our teaching provide opportunities for students to explore [...] commonalities and differences of experience and perspective?" In asking these types of questions during course design, and within approval and validation events alongside faculty and students, library workers can challenge the conceit of library neutrality across our practice and create potentials for students to "critique dominant epistemologies by drawing on those experiences and histories marginalised or silenced in HE curricula" (Burke \& Crozier, 2013 p.14).

\section{Understanding Our Own Deficits as Education Workers}

The author proposes library leadership radically reframe deficit model thinking such that rather than WP students, we understand it is middle-class professionals — and by association our institutions, our libraries — are the ones in deficit based on lacking knowledge rooted in lived experience. This idea is explored using social class as a lens in research by Wilkins \& Burke (2013 
pp.443-445) in which Sarah, Head of Widening Participation at a higher education institution, located her motivation for working within WP within working-class subjectivity. Sarah explains that,

"Largely the people I work with are middle class. I am trying to think of anybody that I work with there are very, very few people who are working class, which is quite interesting, on two levels really. Firstly it means that these people have no real experience of working-class people or working-class life or understanding of workingclass life" (p.444).

In this inversion of the traditional deficit model, Sarah ascribes negative value to middle-class subjectivities and proposes it is middle-class professionals who are lacking "real experience." The critical theory developed by Wilkins \& Burke is not that middle-class education workers cannot do WP work, but that a lack of empathetic understanding developed from authentic knowing creates tensions in which WP "risks becoming a colonizing project for the proselytization of middle-class norms and values" (p.444).

Doing this work requires a shift in our thinking in terms of the cultural and social capitals which we prize most as library and education workers, a developed understanding of the ways identities are multifaceted and oppressions intersectional, and appreciation of the importance of lived experience of marginalized communities alongside theoretical knowledge-including acknowledgement of the relatedness of theoretical knowledge and lived experience. The latter point has been a tension within Critlib movement. For example, in connecting theory and practice Ettarh (2015) explains that, "I learned the words that correctly identified the phenomena that had been occurring (and still are) in my life," or as Hathcock (AprilHathcock, 2015) puts this in reply, "I think this is the case for many of us from marginalized communities. We come to \#critlib as [the academic] node of OUR REAL EXPERIENCES.” hooks (2010) characterizes such ways of knowing and theorizing as practical wisdom, developing an insight which shows "the vital link 
between critical thinking and practical wisdom is the insistence on the interdependent nature of theory and fact coupled with the awareness that knowledge cannot be separated from experience" (p.185).

For a critical librarianship praxis of WP to be relevant to and inclusive of WP students themselves, it must be grounded in the lived experience and knowledge production of communities excluded from and marginalized within higher education. Following Ebert's (1995) concept of ludic feminism, which she critiques as, "a feminism that is founded upon poststructuralist assumptions about linguistic play, difference, and the priority of discourse and thus substitutes a politics of representation for radical social transformation," (p.3) the author cautions against the development of what can be denoted ludic Critlib. Ludic Crilib, complementary with Ebert's ludic feminism and ludic postmodernism, is a critical librarianship practice which redefines the political aspects of librarianship as an academic exercise limited to cultural politics. Ludic Critlib divides theory from the practice and struggle of developing more radical—and materialist—critiques of our leadership practices. Contrary to this, and drawing on Hudson's (2017) call that we "unsettle our assumption that theory and practice represent discrete phenomena with separate lives," our approach to library leadership to be relevant should include close attention to the material inequalities of our society and the ways these are reproduced by the stratification of higher education.

\section{Role-modeling a Critically Reflective Practice}

A Critlib practice of library leadership means being present, and doing the work ourselves and learning with our teams and colleagues across our institutions. It means engaging with discomforting critical dialogue, and understanding how the development of theory forms a living and ongoing argument — that our critical work cannot be self-contained or individualized, but is like any other power relation is "rooted in the system of social networks" (Foucault, 1982 p.793). This implies a critical reflection on practice and a willingness both to challenge our own biases and to lead others in developing their critical consciousness and become involved with intentional, 
intersectional conversations across our institutions. This vital task may be best thought of as an ongoing process, as Fleming \& McBride (2017 p.118) explain "Self-examination is a lifetime of work, but is critical to successfully engaging in and leading anti-oppression work."

Library leaders' ability to make critical strategic moves matters, because along with setting direction at a strategic or policy level within institutions, the ways that leaders role-model these behaviors gives license to colleagues to explore critical practices themselves; with confidence they will be supported and this work valued by leadership. Within neoliberal higher education the dominant imperative for our intellectual work to be practical means this is by no means guaranteed, as Coysh, Denton \& Sloniowski (2018 p.130) pinpoint, "Theorizing — even reflection— is seen as a frill in and environment where we are always crunched for time."

To enable such self-examination, critical reflection is a key skill for leaders to embrace and support within their teams. Critical reflection is a form of reflective practice which includes a sustained focus on assumptions underlying and informing practice, with the aim of bringing these to the surface and unsettling them. This does not mean an introspective mulling over of experience, but is specifically about understanding power relations and the taken-for-granted assumptions which undergird processes of cultural hegemony we have created with academic libraries. For Brookfield, "reflection becomes critical when it's focused on teachers understanding power and hegemony," (2017 p.9) while for Fook \& Gardner critical reflection is "a process (and theory) for unearthing individually held social assumptions in order to make changes in the social world" (2007 p.14). In both cases, the "critical" in critical reflection is based on the authors' drawing from critical theory traditions with an explicit purpose of connecting critical reflection with action affecting our wider institutional, professional, and political contexts. This is to say, with the Freirean notion of transformative interventions in our social worlds. This surfacing and problematizing of hegemonic assumptions is particularly key when, as argued above, it is middle-class professionals who are most likely to be in deficit positions of knowledge and lived experience compared with WP students. 


\section{Concluding Remarks}

This chapter has attempted to apply critical theory approaches to library leadership in ways that can support WP as a practice of social justice. In doing so, Fraser's (2007) multifaceted theory of social justice covering economic, cultural, and political elements was employed as a theoretical frame and critical sociology of education, particularly Burke's research and scholarship, was connected with the developed, rich body of scholarly knowledge of critical information literacy and pedagogy within Critlib movement.

Because access to the cultural and social capitals related to higher educational experiences represents emancipatory power for so many WP students, library leaders may believe we are doing enough in providing access to the learning spaces and information resources which students rely on, and may have lacked within previous educational experiences. Library workers may hold their institutions' commitments to WP as a marker of pride, or use the diversity of their institutions' student and staff body as evidence of alignment between their good intentions and outcomes. As such, suggesting that library leaders at all levels are complicit in reproducing structures of white supremacist capitalist patriarchy may be a source of deep discomfort, or simply rejected outright. Ahmed (2017), however, explains the value of such feelings in motivating us to new learning, as "Discomfort [...] allows things to move. Every experience I have had of pleasure and excitement about a world opening up has begun with such ordinary feelings of discomfort" (pp.132-133).

For leaders, tensions remain based on the instrumentalist approaches that marketized higher education has taken to WP, and even for senior leaders agency can be constrained by both hierarchical organizational structures and dominant discourses of education. In paying criticallyreflective attention to values however, the author argues that leaders can emphasize strategic moves across their institutions and the wider profession of librarianship which support liberatory, rather than hegemonic, practices of WP. In understanding library work holistically as an educational practice, leaders can both support and lead staff in "helping all their students to gain access to the practices and epistemologies that have the greatest social and cultural legitimacy," (Burke, 2012 
p.186) while also supporting political acts of recognition within our everyday work. This vision of widening participation praxis is one that aims to disrupt reproduction of sociocultural inequality within higher education, demonstrating like our parent institutions libraries should be sites of transformation and for the type of dialogic critical conversations which develop "spaces for empathy and opportunities for us to experience our shared humanity" (Bourg, 2014). 


\section{References}

Accardi, M.T. (2013). Feminist pedagogy for library instruction. Sacramento, CA: Library Juice.

Ackerley, C. \& Wilson, T. (2012). Increasing the engagement: widening participation at York. SCONUL Focus, 56, 18-21. Retrieved from https://www.sconul.ac.uk/page/focus-56

Ahmed, S. (2017). Living a feminist life. Durham, NC: Duke University.

Alam, S. (2008). Majority world: challenging the west's rhetoric of democracy. Amerasia Journal, 34(1), 87-98. doi:10.17953/amer.34.1.13176027k4q614v5

albbernardo (2017a, May 25). \#Critlib is now poptimism or sabermetrics, an outsider perspective that's become the mainstream of high-level professional discourse [Twitter post]. Retrieved from https://twitter.com/albbernardo/status/867769563600912384

albbernardo (2017b, May 25). And one to which you must subscribe if you want to be taken seriously, or part of the in-crowd [Twitter post]. Retrieved from https://twitter.com/albbernardo/status/867769989759090688

Anderson, L. \& Bull, S. (2014). The creation of a university library outreach programme to develop the information literacy of further education students: an interactive approach to support student transition. Journal of Information Literacy, 8(1), 42-57. doi:10.11645/8.1.1853

AprilHathcock (2015, December 16). I think this is the case for many of us from marginalized communities. We come to \#critlib as acad node of OUR REAL EXPERIENCES. [Twitter post]. Retrieved from https://twitter.com/AprilHathcock/status/677131009964580864

Equality Challenge Unit (2019). Use of language: race and ethnicity. Retrieved from https://www.ecu.ac.uk/guidance-resources/using-data-and-evidence/use-language-raceethnicity/

Barron, S. \& Preater, A.J. (2018). Critical systems librarianship. In K.P Nicholson \& M. Seale (Eds.), The politics of theory and the practice of critical librarianship (pp. 87-110). Sacramento, CA: Library Juice.

Beatty, J.F. (2015, June). Reading Freire for first world librarians. Paper presented at the meeting of the Canadian Association of Professional Academic Librarians, Ottawa, ON. Retrieved from https://dspace.sunyconnect.suny.edu/handle/1951/70036

Becker, G.S. (1993). Human capital: a theoretical and empirical analysis. (3rd ed.) Chicago, IL: University of Chicago.

Bhopal, K. (2018). White privilege: the myth of a post-racial society. Bristol: Policy.

Bourdieu, P. (1986). The forms of capital. In J. Richardson (Ed.) \& R. Nice (Trans.). Handbook of theory and research for the sociology of education (pp.241-258). New York, NY: Greenwood.

Bourdieu, P. (1993). The field of cultural production (R. Johnson, Trans.). New York, NY: Columbia University.

Bourg, C. (2014, October 25). Librarianing to transgress: closing keynote ACRL OR/WA 2014 [Web log post]. Retrieved from https://chrisbourg.wordpress.com/2014/10/25/librarianingto-transgress-closing-keynote-acrl-orwa-2014/ 
Brookfield, S.D. (2017). Becoming a critically reflective teaching (2nd ed.) San Francisco, CA: Jossey-Bass.

Brown, R. \& Carasso, H. (2013). Everything for sale? The marketisation of UK higher education. London: Routledge.

Brown, R. (2018). Public lecture: neoliberalism, marketisation and higher education [Video file]. Retrieved from https://www.youtube.com/watch?v=oAg1CVuKAxE

Burke, P.J. (2012). The right to higher education: beyond widening participation. Abingdon: Routledge.

Burke, P.J., Bennett, A., Bunn, M., Stevenson, J. \& Clegg, S. (2017). It's about time: working towards more equitable understandings of the impact of time for students in higher education. Retrieved from https://www.ncsehe.edu.au/publications/its-about-time-workingtowards-more-equitable-understandings-of-the-impact-of-time-for-students-in-highereducation/

Burke, P.J., Bennett, A., Burgess, C., Gray, K. \& Southgate, E. (2016). Capability, belonging and equity in higher education: developing inclusive approaches. Retrieved from https://www.ncsehe.edu.au/publications/capability-belonging-and-equity-in-highereducation-developing-inclusive-approaches/

Burke, P.J., \& Crozier, G. (2013). Teaching inclusively: changing pedagogical spaces. Retrieved from

https://www.newcastle.edu.au/_data/assets/pdf_file/0004/305968/UN001_Teaching_Inclusi vely_Resource_Pack_Online.pdf

Burke, P.J. \& Crozier, G. (2014, June). Regulating difference in higher education pedagogies. Paper presented at Governing Academic Life 2014 conference, London, UK.

Burke, P.J. \& Jackson, S. (2007). Reconceptualising lifelong learning: feminist interventions. Abingdon: Routledge.

Burke, P.J., \& Lumb, M. (2018). Researching and evaluating equity and widening participation: praxis-based frameworks. In Burke, P.J., Hayton, A. \& Stevenson, J. (Eds.), Evaluating equity and widening participation in higher education (pp.11-32). Stoke-on-Trent: Trentham.

Burns, J.M. (1978). Leadership. New York, NY: Harper Row.

Collins, P.H. (1989). The social construction of Black feminist thought. Signs, 14(4), 745-773. doi:10.1086/494543

Coysh, S.J., Denton, W. \& Sloniowski, L. (2018). Ordering things. In K.P Nicholson \& M. Seale (Eds.), The politics of theory and the practice of critical librarianship (pp. 129-144). Sacramento, CA: Library Juice.

Crenshaw, K. (1989). Demarginalizing the intersection of race and sex: a Black feminist critique of antidiscrimination doctrine, feminist theory and antiracist politics. University of Chicago Legal Forum, 1989(1), 139-167. Retrieved from http://chicagounbound.uchicago.edu/uclf/vol1989/iss1/8 
Cripps, E., Anderson, C., Strauss, P. \& Wheeler, R. (2018). Fostering independent research skills and critical enquiry among school students: a case study of a school-university partnership to support the extended project qualification. Research for All, 2(2), 323-334. doi:10.18546/RFA.02.2.10

Critlib (n.d.). About/join the discussion. Retrieved from http://critlib.org/about/

Crozier, G. \& Reay, D. (2011). Capital accumulation: working-class students learning how to learn in HE. Teaching in Higher Education, 16(2), 145-155. doi:10.1080/13562517.2010.515021

Dick, A.L. (1995). Library and information science as a social science: neutral and normative conceptions. The Library Quarterly, 65(2), 216-235. doi:10.1086/602777

Diaz, S.A. (2019). Outreach in academic librarianship: a concept analysis and definition. The Journal of Academic Librarianship, 45(3), 184-194. doi:10.1016/j.acalib.2019.02.012

Drabinski, E. (2013). Queering the catalog: queer theory and the politics of correction. The Library Quarterly, 83(2), 94-111. doi:10.1086/669547

Drabinski, E., Kumbier, A. \& Accardi, M. (Eds.) (2010). Critical library instruction: theories and methods. Sacramento, CA: Library Juice.

Ebert, T.L. (1995). Ludic feminism and after: postmodernism, desire, and labor in late capitalism. Ann Arbor, MI: University of Michigan.

Elmborg, J. (2006). Critical information literacy: implications for instructional practice. The Journal of Academic Librarianship, 32(2), 192-199. doi:10.1016/j.acalib.2005.12.004

Ettarh, F. (2015, December 15). \#whyicritlib. Retrieved from https://thetokentwo.wordpress.com/2015/12/15/whycritlib/

Equality Challenge Unit (2019). Use of language: race and ethnicity. Retrieved from https://www.ecu.ac.uk/guidance-resources/using-data-and-evidence/use-language-raceethnicity/

Fleming, R. \& McBride, K. (2017). How we speak, how we think, what we do: leading intersectional feminist conversations in libraries. In Lew, S. \& Yousefi, B. (Eds.), Feminists among us (pp 107-125). Sacramento, CA: Library Juice.

Fook, J. \& Gardner, F. (2007). Practising critical reflection: a resource handbook. Maidenhead: Open University.

Foucault, M. (1995). Discipline and punish: the birth of the prison (A. Sheridan, Trans.). (2nd ed.). New York, NY: Vintage.

Foucault, M. (1982). The subject and power, Critical Enquiry, 8(4), 777-795. doi:10.1086/448181

Fraser, N. (2003). Social justice in the age of identity politics: redistribution, recognition, and participation. In Fraser, N. \& Honneth, A., Redistribution or recognition? A politicalphilosophical exchange (pp.7-109). London: Verso.

Fraser, N. (2007). Re-framing justice in a globalizing world. In Lovell, T. (Ed.), (Mis)recognition, social inequality and social justice (pp.17-35). London: Routledge.

Freire, P. (1994). Pedagogy of hope (R.E. Barr, Trans). London: Bloomsbury. 
Freire, P. (1996). Pedagogy of the oppressed (M.B. Ramos, Trans.). London: Penguin.

Freire, P. (2005). Education for critical consciousness (M.B. Ramos, Trans.). London: Continuum.

Galvan, A.S. (2015). Soliciting performance, hiding bias: whiteness and librarianship. In the Library With the Lead Pipe, 2015. Retrieved from http://www.inthelibrarywiththeleadpipe.org/2015/soliciting-performance-hiding-biaswhiteness-and-librarianship/

Goulding, A. (2008). Libraries and cultural capital. Journal of Librarianship and Information Science, 40(4), 235-237. doi:10.1177/0961000608096713

Gorard, S., Smith, E., May, H., Thomas, L., Adnett, N. \& Slack, K. (2006). Review of widening participation research: addressing the barriers to participation in higher education. Retrieved from https://dera.ioe.ac.uk/6204/1/barriers.pdf

Gramsci, A. (1971). Selections from the prison notebooks (Q. Hoare \& G.N. Smith, Trans.). London: Lawrence \& Wishart.

Grant, B. (1997). Disciplining students: the construction of student subjectivities. British Journal of Sociology of Education, 18(1), 101-114. doi:10.1080/0142569970180106

Hall, S. (1996). Who needs identity? In S. Hall, \& P. Du Gay (Eds.), Questions of Cultural identity (pp.1-17). London: Sage.

Hathcock, A. (2015). White librarianship in blackface: diversity initiatives in LIS. In the Library With the Lead Pipe, 2015. Retrieved from http://www.inthelibrarywiththeleadpipe.org/2015/lis-diversity/

HESA (n.d.). Changes to the UK performance indicators. Retrieved from https://www.hesa.ac.uk/data-and-analysis/performance-indicators/changes

HESA (2018). Widening participation: UK performance indicators 2016/17. Retrieved from https://www.hesa.ac.uk/news/01-02-2018/widening-participation-tables

Hinton-Smith, T. (2012). Introduction. In Hinton-Smith, T. (Ed.), Widening participation in higher education: casting the net wide? (pp.3-21). London: Palgrave Macmillan.

Hollister, C, Brower, S. \& Schroeder, R. (2017, May). Ten years of expanding the information literacy landscape. Paper presented at the Workshop for Instruction in Library Use 2017, Edmonton, AB. doi:10.7939/R3X63BJ8M

hooks, b. (1984). Feminist theory: from margin to center. Boston, MA: South End.

hooks, b. (2010). Teaching critical thinking: practical wisdom. Abingdon: Routledge.

Horkheimer, M. (2012). Critique of instrumental reason (M.J. O’Connell, Trans.). London: Verso.

Hudson, D.J. (2017). The whiteness of practicality. In G. Schlesselman-Tarango (Ed.), Topographies of whiteness: mapping whiteness in library and information studies (pp.203234). Sacramento, CA: Library Juice.

Hudson, D.J. (2016, February). On critical librarianship \& pedagogies of the practical. Paper presented at the Critical Librarianship and Pedagogy Symposium, Tucson, AZ. Retrieved from https://repository.arizona.edu/handle/10150/612654 
Hussain, L. (2015). Why is my curriculum white? Retrieved from https://www.nus.org.uk/en/news/why-is-my-curriculum-white/

Hussey, L. (2010). Social capital, symbolic violence, and fields of cultural production: Pierre Bourdieu and library and information science. In G.J. Leckie, L.M. Given, \& J.E. Buschman (Eds.), Critical theory for library and information science (pp.41-51). Santa Barbara, CA: Libraries Unlimited.

Jackson, B. \& Marsden, D. (1966). Education and the working class. London: Penguin.

Kapitzke, C. (2003). (In)formation literacy: a positivist epistemology and a politics of (out)formation. Educational Theory, 53(1), 37-53. doi:10.1111/j.1741-5446.2003.00037.x

Kincheloe, J., \& Steinberg, S. (1997). Changing multiculturalism. Buckingham: Open University.

Labour Party (2001). Ambitions for Britain: Labour's manifesto 2001. Retrieved from http://www.politicsresources.net/area/uk/e01/man/lab/ENG1.pdf

Lebeau, Y. \& Bennion, A. (2014). Forms of embeddedness and discourses of engagement: a case study of universities in their local environment. Studies in Higher Education, 39(2), 278293. doi:10.1080/03075079.2012.709491

Pagowsky, N. \& McElroy, K. (Eds.) (2016a). Critical library pedagogy volume 1: essays and workbook activities. Chicago, IL: Association of College and Research Libraries.

Pagowsky, N. \& McElroy, K. (Eds.) (2016b). Critical library pedagogy volume 2: lesson plans. Chicago, IL: Association of College and Research Libraries.

Mavelli, L. (2014). Widening participation, the instrumentalization of knowledge and the reproduction of inequality. Teaching in Higher Education, 19(8), 860-869. doi:10.1080/13562517.2014.934352

Miller, J. (1995). Trick or Treat? The autobiography of the question. English Quarterly, 27(3), pp.22-26.

Millburn, A. (2013). Higher education: the fair access challenge. Retrieved from https://www.gov.uk/government/publications/higher-education-the-fair-access-challenge

Office for Students (2018a). A new approach to regulating access and participation in English higher education: consultation outcomes. Retrieved from https://www.officeforstudents.org.uk/publications/a-new-approach-to-regulating-access-andparticipation-in-english-higher-education-consultation-outcomes/

Office for Students (2018b). Regulatory notice 1. Access and participation plan guidance for 201920. Retrieved from https://www.officeforstudents.org.uk/media/1093/ofs2018_03.pdf

Office for Students (2018c). A new approach to regulating access and participation in English higher education. Retrieved from https://www.officeforstudents.org.uk/media/6ad50390eb57-4230-923a-0e0d53d672ac/access-and-participation-consultation-event-slides.pdf

Read, B. Archer, L. \& Leathwood, C. (2003). Challenging cultures? Student conceptions of 'belonging' and 'isolation' at a post-1992 university. Studies in Higher Education, 28(3), 261-277. doi:10.1080/03075070309290 
Reay, D. (2001). Finding or losing yourself?: Working-class relationships to education. Journal of Education Policy, 16(4), 333-346. doi:10.1080/02680930110054335

Reay, D. (2018). Miseducation: inequality, education and the working class. Bristol: Polity.

Reay, D. , Crozier, G. \& Clayton, J. (2013). 'Fitting in' or 'standing out': working-class students in UK higher education. British Educational Research Journal, 36(1), 107-124. doi:10.1080/01411920902878925

Riedsma, M. (2019). Masked by trust: bias in library discovery. Sacramento, CA: Library Juice.

Rickard, K. (2016). Academic library outreach: a view from the field (Master's dissertation). Retrieved from https://pure.aber.ac.uk/portal/files/28175037/Rickard_Katie.pdf

Schroeder, R. \& Hollister, C.V. (2014). Librarians' views on critical theories and critical practices. Behavioral and Social Sciences Librarian, 33(2), 91-119. doi:10.1080/01639269.2014.912104

Skeggs, B. (1997). Formations of class and gender. London: Sage.

Skeggs, B. (2003). Class, self, culture. London: Routledge.

Stevenson, J. \& Clegg, S. (2013). 'My past is a double edge sword': temporality and reflexivity in mature learners. Studies in Continuing Education, 35(1), 17-29. doi:10.1080/0158037X.2012.684794

Stevenson, J., O’Mahony, J., Khan, O., Ghaffar, F. \& Stiell, B. (2019). Understanding and overcoming the challenges of targeting students from under-represented and disadvantaged ethnic backgrounds. Retrieved from https://www.officeforstudents.org.uk/publications/understanding-and-overcoming-thechallenges-of-ethnicity-targeting/

Terrile, V.C. (2019). Critical pedagogies to combat the deficit model in community college libraries: a perspective. The Journal of Academic Librarianship. doi:10.1016/j.acalib.2019.02.003

Tewell, E. (2015). A decade of critical information literacy: a review of the literature.

Communications in Information Literacy, 9(1), 24-43. Retrieved from http://comminfolit.org/index.php?journal=cil\&page=article\&op=view\&path $\% 5 \mathrm{~B} \% 5 \mathrm{D}=\mathrm{v} 9 \mathrm{i} 1$ $\mathrm{p} 24$

Thompson, E., Phipps, L. \& Fitzpatrick, A. (2018, March). Going where the wild students are! Panel discussion at Jisc DigiFest 2018, Birmingham, UK.

Webb, S. Burke, P.J., Nichols, S., Roberts, S., Stahl, G., Threadgold S., \& Wilkinson, J. (2017). Thinking with and beyond Bourdieu in widening higher education participation. Studies in Continuing Education, 39(2), 138-160. doi:10.1080/0158037X.2017.1302926

Wilkins. A. \& Burke, P.J. (2015). Widening participation in higher education: the role of professional and social class identities and commitments. British Journal of Sociology of Education, 36(3), 434-452. doi:10.1080/01425692.2013.829742

Yosso, T.J. (2005). Whose culture has capital? A critical race theory discussion of community cultural wealth. Race Ethnicity and Education, 8(1), 69-91. doi:10.1080/1361332052000341006 